\title{
KARAKTERISTIK TIPE DASAR DAN PEMANFAATAN PERAIRAN DI SEKITAR PULAU GANGGA, KABUPATEN MINUT
}

\author{
Wilhelmina Patty \\ Staf Pengajar pada Program Pemanfaatan Sumberdaya Perikanan \\ Fakultas Perikanan dan IImu Kelautan. UNSRAT. Manado 95115.
}

\begin{abstract}
Coastal resources and space in the coastal around Gangga island, has been used for fishing activities and marine tourism. The purpose of this study to map the profile of bottom waters and to identify patterns sublitoral basic surface waters. The survey was conducted by using the acoustic method of sounding, followed by sediment sampling as well as shooting on the surface of the bottom waters. The result of observation indicates that the basic conditions of slope waters around the island of Ganga slope varies from flat to very steep slopes. Waters of the western Gangga island smaller flat slope found in coastal landform ranging from mangroves, coral reefs and seagrass. Bottom waters to the east of Gangga island to steep slope, with the basic pattern dominated by coral reefs and sand.
\end{abstract}

Keywords : sub-littoral waters, Acoustic, coral reef, Gangga Island

\section{PENDAHULUAN}

Pemahaman tentang keberadaan lingkungan pesisir dan lautan sangat dibutuhkan dalam pemanfaatan dan pengelolaan wilayah pesisir termasuk didalamnya pengetahuan tentang morfologi dan sedimen dasar laut (Dahuri, dkk., 2001; Davis Jr. 1991). Morfologi pantai sangat dipengaruhi oleh arus, pasut dan gelombang, dimana arus yang lemah tidak dapat mengangkut sedimen berbutiran kasar, tetapi dapat mengangkut sedimen berbutiran halus. Pemanfaatan kawasan pesisir dan pulaupulau kecil telah dan sementara dilakukan diberbagai wilayah termasuk Sulawesi Utara yang tergolong sebagai provinsi kepulauan. Salah satu diantaranya yaitu gugusan kepulauan Gangga-Bangka-Talise yang berada di bagian utara Semenanjung Minahasa yang saat ini mulai dimanfaatkan pada sektor perikanan dan pariwisata kebaharian. Adanya pemanfaatan tersebut tidak menutup kemungkinan lahan pantai mengalami perubahan geomorfologi karena efektivitas intervensi dan kesinambungan upaya manusia memanfaatkan dan mendayagunakan kawasan pantai.

Penelitian ini dilakukan dengan tujuan untuk mengidentifikasi tipe dasar perairan dan memetakan profil dasar perairan di wilayah sekitar Pulau Gangga. Hasil ini sangat berguna untuk perikanan tangkap dan budidaya. Juga dapat digunakan sebagai data dasar atau sumber informasi tentang perubahan yang terjadi pada permukaan bumi sebagai akibat proses hidrodinamika (seperti arus dan gelombang), atau aktivitas antropogenik.

\section{METODE PENELITIAN}

Pengambilan data kedalaman perairan di sekitar pulau Gangga beserta penarikan contoh sedimen yang menghampari dasar perairan tersebut dilakukan dengan menggunakan peralatan Fish finder yang dipasang pada perahu bermotor dengan mengikuti jalur transek seperti terlihat pada Gambar 1. Pengukuran dilakukan dengan cara mengikuti kordinat lintang untuk memudahkan proses pengambilan data yang dimulai dari kedalaman 1 meter ke arah laut sampai pada batas sesuai keadaan di lapangan. Untuk jalur berikutnya diukur dari arah laut ke arah darat sampai pada kedalaman 1 meter. Hal ini berulang sampai pada transek terakhir. Penentuan arah dan posisi jalur pemeruman (sounding) akan dibantu dengan kompas dan GPS. Pengambilan data posisi geografis dan kedalaman dasar laut, dilakukan setiap penambahan atau pengurangan 0,5 detik pada posisi bujur ke arah timur atau barat. Contoh sedimen dasar diambil pada beberapa stasiun, dengan menggunakan Grab sampler yang 
disesuaikan dengan kondisi dasar perairan. Analisis granulometri sedimen dilakukan menurut skala AFNOR (Chamley, 1997).

Kemiringan (profil) dasar perairan digambarkan berdasarkan perubahan kedalaman permukaan dasar laut sepanjang garis transek. Penentuan profil pantai ditentukan berdasarkan nilai koefisien regresi (b $\%)$ dari persamaan $y=a+b x$ dimana y adalah kedalaman perairan dan $x$ adalah jarak dari garis pantai ke setiap titik kedalaman yang diukur. Menurut Sunarto, (1991) kriteria klasifikasi kemiringan lereng terdiri dari: lereng datar $(0,0-2,9 \%)$, lereng landai $(3,0-$ $7,9 \%)$, lereng miring $(8,0-13,9 \%)$, lereng sangat miring $(14,0-20,9 \%)$, lereng curam $(21,0-55,9 \%)$, lereng sangat curam (56$140,9 \%)$ dan lereng terjal (>140,9\%).

\section{HASIL DAN PEMBAHASAN}

\section{Kedalaman Perairan dan Corak Morfografi Dasar Perairan.}

Kedalaman perairan sekitar Pulau Gangga bervariasi antara 0,4m-56,0m. Pada pantai bagian timur memiliki tingkat kedalaman yang lebih besar, dengan gradien yang sangat nyata dibandingkan dengan pantai bagian Barat (Gambar 2). Perubahan kedalaman di pantai bagian barat terlihat secara bertahap dan lebih lebar, sedangkan di bagian timur, perubahan kedalaman sangat sempit atau interval setiap perubahan kedalaman sangat dekat, kecuali pada bagian tenggara, terlihat perubahan dasar perairan teratur, bertahap dan interfal perubahan kedalaman yang berjauhan.

Analisa hasil perhitungan kemiringan dasar perairan mulai dari garis pantai ke arah laut menunjukan bahwa dasar perairan sekitar pulau Gangga memiliki kemiringan dasar perairan berkisar $2-70 \%$ atau tergolong dalam tipe lereng datar sampai pada tipe lereng sangat curam. Pada bagian barat memiliki kemiringan dasar perairan yang lebih kecil dari pada di pantai bagian timur pulau (Gambar 3a dan b).

Umumnya, wilayah pesisir bagian Barat P. Gangga memiliki pantai berlereng miring dan di wilayah ini dimanfaatkan oleh penduduk sebagai lokasi pemukiman (Desa Gangga 1 dan Gangga 2) karena aman dari pengaruh gelombang yang besar. Menurut Triatmodjo, (1999), kemiringan lereng mempunyai pengaruh langsung terhadap gelombang yang datang ke garis pantai. Semakin dangkal suatu perairan maka gelombang yang datang akan mengalami pembelokan (refraksi) sehingga terjadi pengurangan tinggi gelombang.

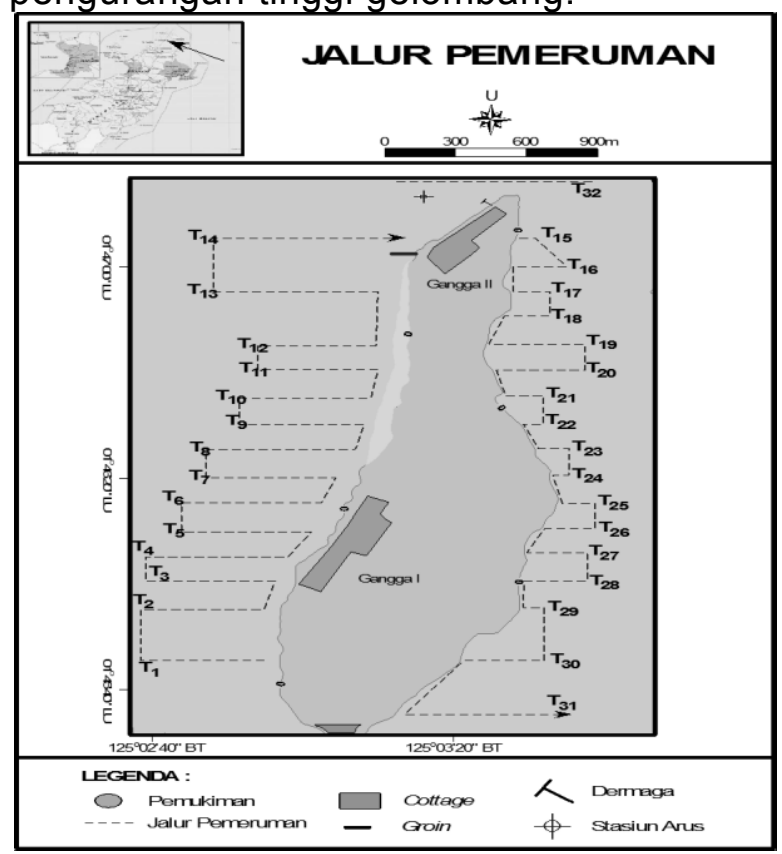

Gambar 1. Lokasi penelitian dan jalur pemeruman di perairan sekitar Pulau Gangga.

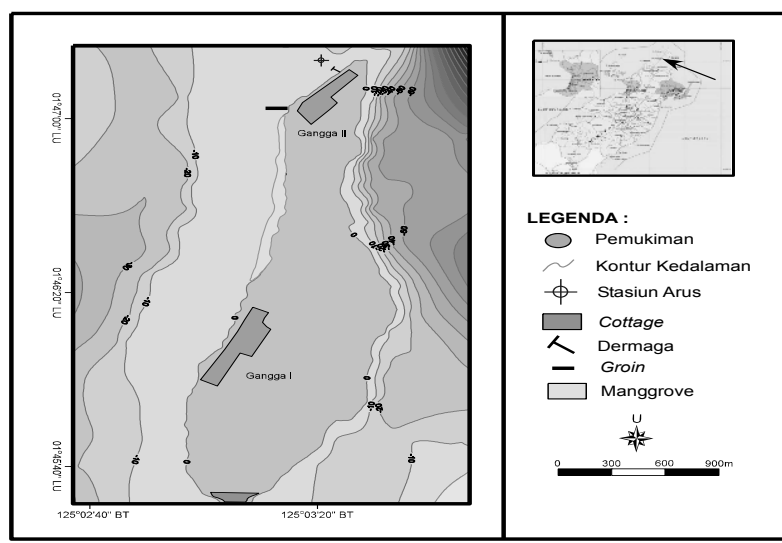

Gambar 2. Kontour Dasar perairan sekitar Pulau Gangga.

Kondisi kemiringan dasar perairan di Transek 1, dimulai dengan pantai berlereng miring dan selanjutnya semakin ke arah laut (sampai $\pm 400 \mathrm{~m}$ dari garis pantai) dasar perairannya semakin datar. Sehingga di daerah ini dimanfaatkan sebagai lokasi wisata bahari dan di sana sudah dibangun Gangga Resort. Kondisi ini hampir sama dengan di lokasi Transek 3, yang memiliki kemiringan pantai landai.

Pada Transek 5, yang terletak di depan Desa Gangga 1, kemiringan dasar perairan termasuk lereng landai, dan agak me- 


\section{Karakteristik Tipe Dasar Perairan Pulau Gangga}

lebar sampai pada jarak $\pm 100 \mathrm{~m}$ dari garis pantai. Kondisi ini mempengaruhi pemanfaatan wilayah pesisir sebagai sarana transportasi terutama pada waktu air surut.

Kondisi dasar perairan di transek lainnya (Tr. 7, 9, 11 dan 14) adalah berlereng miring sampai pada jarak $\pm 100 \mathrm{~m}$ dari garis pantai, selanjutnya berlereng curam.

Pada bagian timur P. Gangga, kemiringan dasar perairan sangat bervariasi mulai dari lereng datar sampai dengan sangat curam (Gambar 3b). Pantai berlereng lebih kecil seperti lereng datar dijumpai pada Transek 31 (bagian Tenggara) dan lereng landai yang dijumpai pada Transek 21. Pada lokasi itu dimanfaatkan sebagai tempat wisata bahari. Sedangkan pantai berlereng lebih besar seperti pantai lereng curam dan sangat curam ditemukan pada Transek 16 dan 18 yakni di bagian timur laut. Pesisir daerah ini adalah tebing batu dan sedimen dasar didominasi oleh karang.

\section{Distribusi Partikel Sedimen}

Ukuran sedimen yang dicuplik pada beberapa lokasi di wilayah pesisir Pulau Gangga menggambarkan variasi ukuran sedimen menurut lokasi pengambilan (Gambar 4). Di bagian barat mulai dari Transek 1-7 didominasi oleh partikel pasir sedangkasar (Gambar 4a). Hal ini juga ditunjang dengan tingkat kemiringan lahan yang kecil (landai). Sehingga wilayah ini banyak dimanfaatkan sebagai lokasi pemukiman penduduk, alur transportasi, serta sarana pariwisata Bahari. Kondisi yang sama juga dijumpai di bagian tenggara Pulau Gangga yakni pada Transek 30-31 (Gambar 4b).

Pada lokasi Transek 12-14, prosentasi kehadiran ukuran sedimen mulai dari pasir halus, sedang, kasar, karang dan batu relatif dalam jumlah yang sama (Gambar 4c). Keberadaan hutan mangrove, lamun dan terumbu karang berfungsi sebagai penahan gerakan air sehingga partikel berukuran halus dapat diendapkan. Khusus di lokasi Transek 13 yang terletak di daerah bertanjung, sehingga memiliki tingkat kemiringan lahan yang tinggi (miring sampai curam) menyebabkan diendapkannya subtrat kasar. Aksi gelombang cukup tinggi, sehingga pada beberapa bagian terlihat abrasi pantai dan kerusakan mangrove.
Di bagian timur Pulau Gangga, seperti yang teramati pada Transek 16 dengan kemiringan lahan yang lebih besar, menyebabkan dasar perairan lebih didominasi oleh subtrat kasar seperti batu, karang dan pasir kasar (Gambar 4d). Hal ini mengindikasikan peranan kekuatan arus dan gelombang yang bekerja dalam mendepositkan partikel berukuran lebih besar pada lokasi tersebut.

Pethick (1997) menyatakan bahwa ukuran sedimen dipengaruhi oleh kemiringan lereng dasar perairan. Semakin kecil ukuran partikel sedimen maka lereng akan landai sebaliknya bila ukuran partikel semakin besar maka kemiringan lereng akan curam. Kondisi lereng yang curam sampai dengan sangat curam dapat menyebabkan aksi gelombang yang sangat kuat dan menyebabkan proses erosi, serta membongkar dan mentransfer sedimen tersebut. Hal ini dapat dilihat pada sedimen ukuran besar yang dominan di Transek 16, yang kemungkinan disebabkan oleh pecahan dinding karang akibat aksi gelombang laut.

Menurut Sulistiyo dalam Rais $d k k$., (2004) bahwa daya penghancur ombak terhadap daratan atau batuan dipengaruhi oleh beberapa faktor antara lain keterjalan garis pantai, kekerasan batuan, kedalaman laut di depan pantai, bentuk pantai, terdapat atau tidaknya barier di depan pantai.

\section{KESIMPULAN}

Dasar perairan memiliki tingkat kemiringan kecil atau lereng datar sampai kemiringan besar atau lereng sangat curam.

Pantai barat Pulau Gangga secara umum lebih didominasi oleh pantai berlereng miring dan melebar ke arah laut. Kondisi seperti ini juga dijumpai di beberapa lokasi bagian timur. Pada lokasi tersebut sedimen yang dominan adalah pasir kasar sampai dengan pasir halus, sehingga lokasi ini sudah dimanfaatkan sebagai lokasi pemukiman dan wisata bahari, juga sebagai tempat tambatan perahu.

Khusus di bagian timur laut Pulau Gangga, kondisi dasar laut tergolong lereng sangat curam dan sedimen di lokasi ini didominasi oleh batu sampai pasir kasar. 

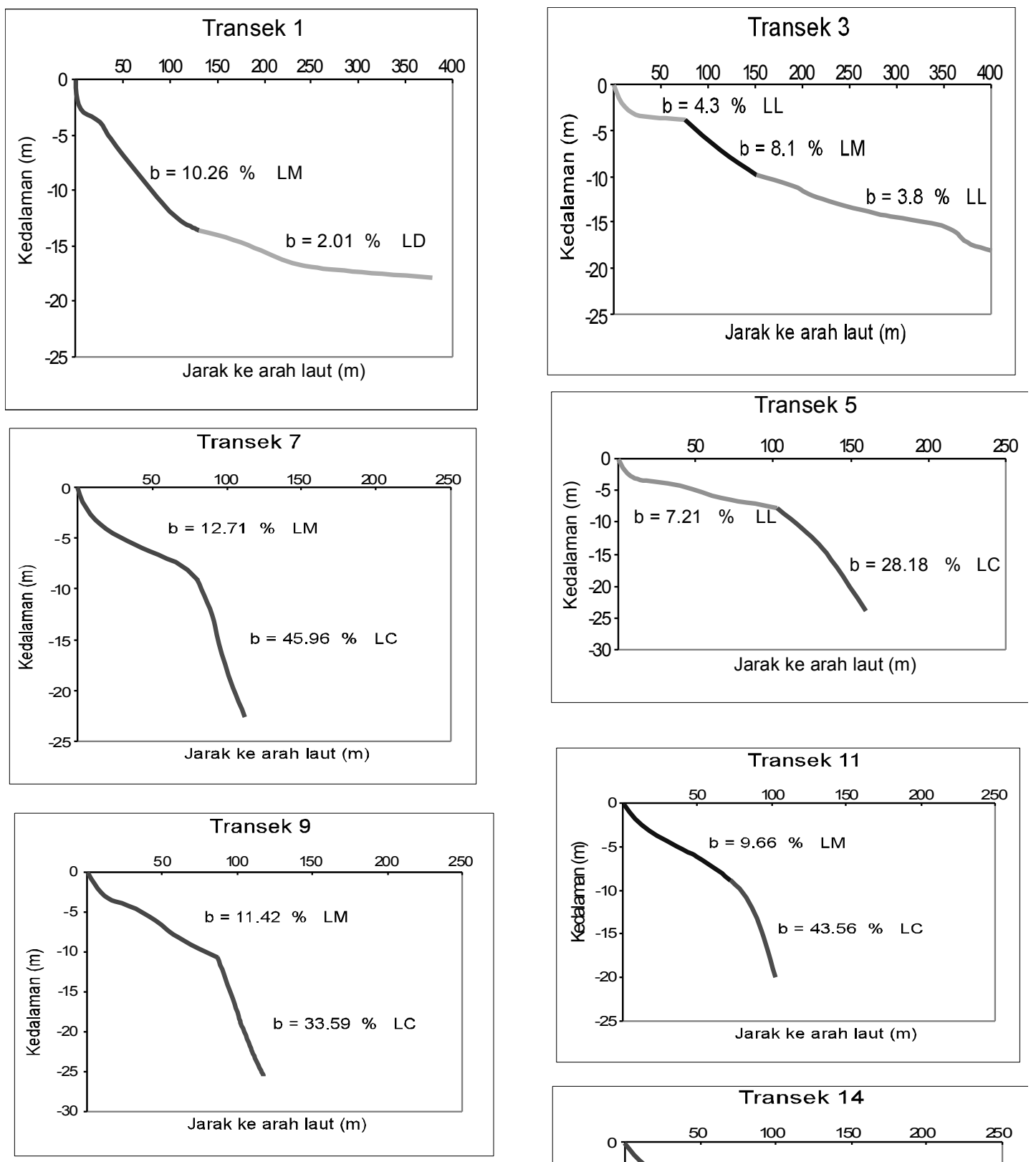

Keterangan :

LD : Lereng Datar
LC : Lereng Curam
LM : Lereng Miring
LL : Lereng Landai
LSM : Lereng Sangat Curam

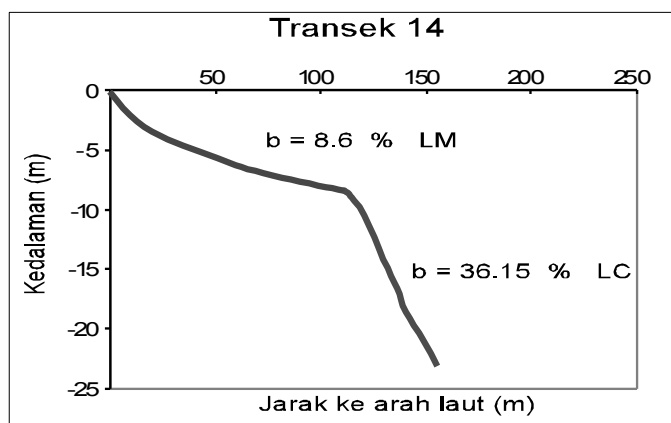

Gambar 3a. Kemiringan dasar perairan (profil) di pantai Barat pulau Gangga 
Karakteristik Tipe Dasar Perairan Pulau Gangga
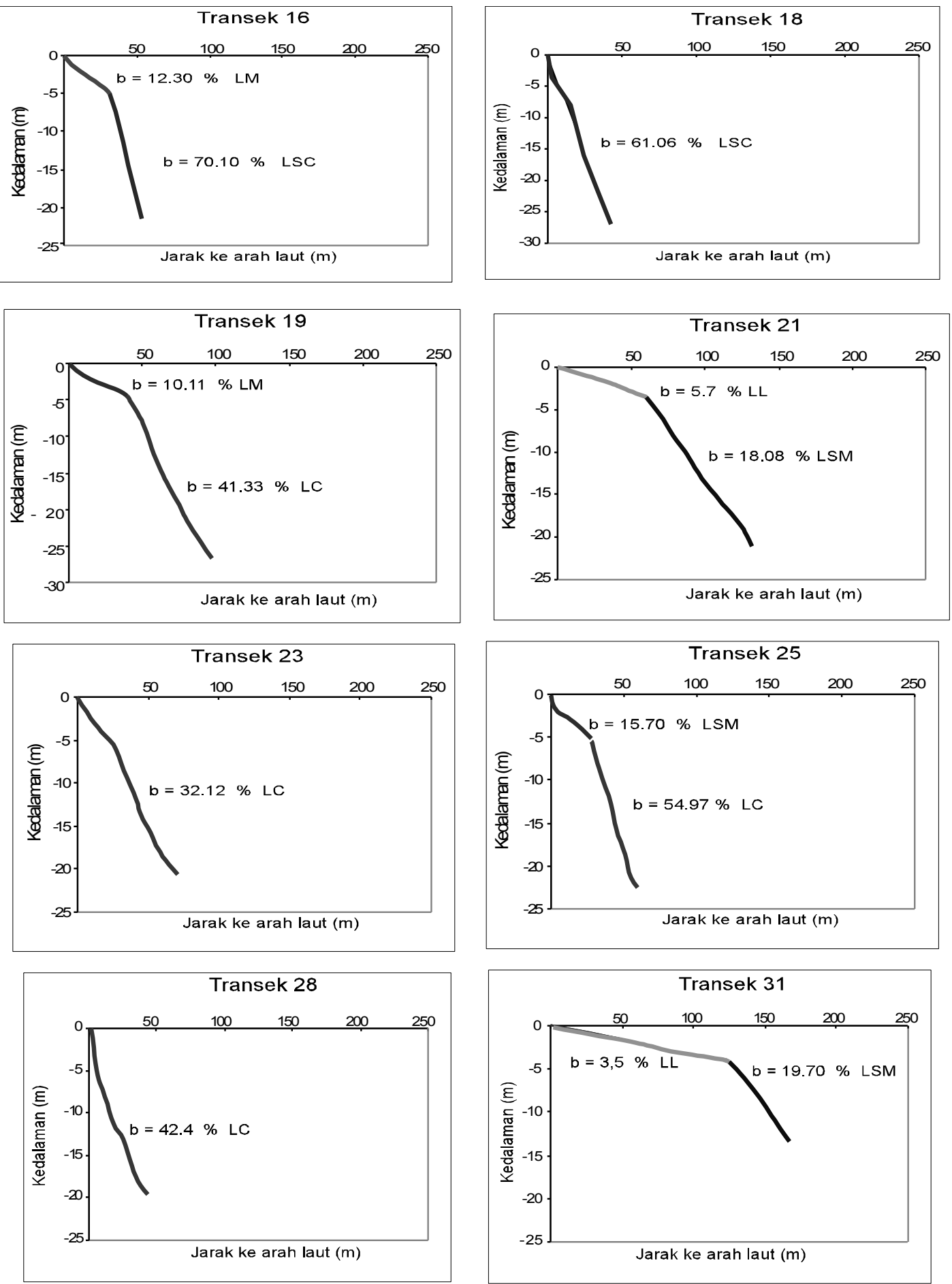

Keterangan : LD : Lereng Datar LL : Lereng Landai LSM : Lereng Sangat Curam LC : Lereng Curam LM : Lereng Miring

Gambar 3b. Kemiringan dasar perairan (profil) di pantai Timur pulau Gangga 
A

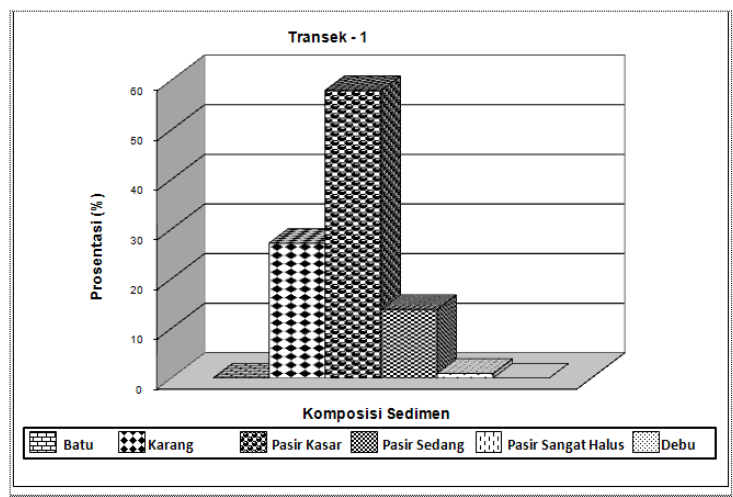

C

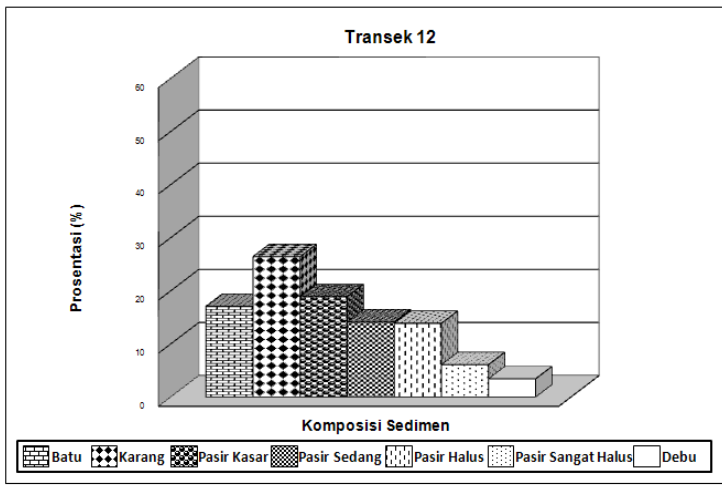

B

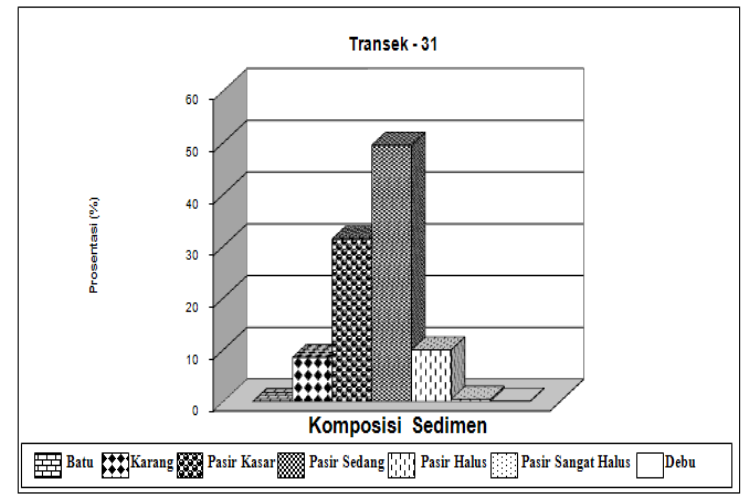

D

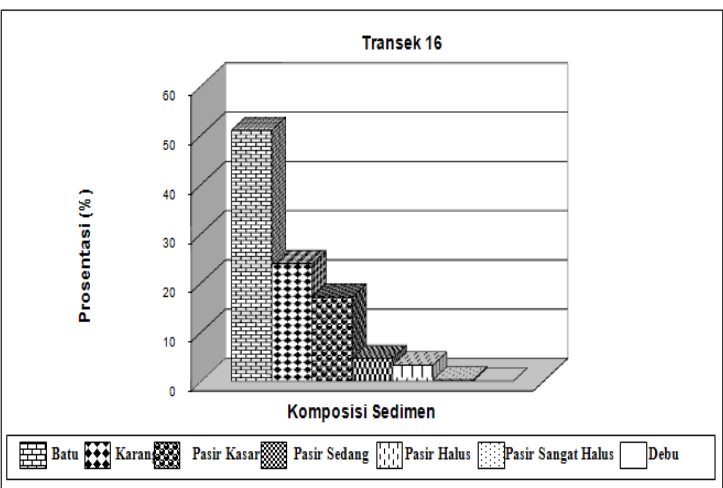

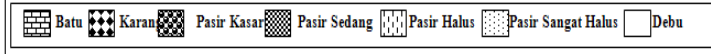

\section{DAFTAR PUSTAKA}

Chamley, H., 1997. Sédimentologie. Collection Geosciences-Dunod, Paris. 175 hal

Dahuri, R., J. Rais, S.P. Ginting. M.J. Sitepu, 2004. Pengelolaan Sumber daya Wilayah Pesisir dan Lautan Secara Terpadu. PT. Pradnya Paramita Jakarta. 328 hal.

Misund, 1993. Abundance estimation of fish schools based on relationship between school area and school biomass. Aquat living Resour., 6: 235-241.

Nybakken, J.W. 1992. Biologi laut, Suatu pendekatan Ekologis. P.T. Gramedia. Jakarta. 458 hal.
Petchik, J. 1997. An Introduction to Coastal Geomorphology. Edward Arnold Division of Hodder and Stougthon. London. 259 hal.

Rais., J., Sulistiyo,B., Diamar,S., Gunawan, T., Sumampouw., M. Soeprapto, Suhardi, Karsidi, dan Widodo, S. 2004. Menata Ruang Laut Terpadu. PT Pradnya Paramita. Jakarta.249 hal.

Sunarto, 1991. Geomorphologi Pantai. Pusat Antar Universitas; UGM-Yogyakarta, 52 hal.

Sutikno, 1999. Karakteristik Bentuk Pantai, "Diktat", Yogyakarta: PUSPICS UGM. 